\title{
Quality of Life during Neoadjuvant Therapy for Patients with Esophageal Cancer
}

\author{
Maria Teresa Santos Guedes ${ }^{1}$, Maria Aparecida de Luca Nascimento ${ }^{2}$, \\ Mônica Porto ${ }^{3}$, Marysse Lanes ${ }^{4}$, Flávio Duarte Sabino ${ }^{5}$ \\ ${ }_{1,3,4}$ Oncology nurses - Outpatient Clinic of the Cancer Hospital I, Brazilian National Cancer Institute. \\ ${ }^{2}$ Nurse PHD - Postgraduate Program in Nursing and Biosciences, Universidade Federal do Estado do Rio de \\ Janeiro - UNIRIO. \\ ${ }^{5}$ Surgeon of the Abdominopelvic Surgery Section of the Cancer Hospital I, Brazilian National Cancer Institute.
}

\begin{abstract}
Background: Esophageal cancer is in eighth position among the most common types in the world. Approximately $80 \%$ of cases occur in underdeveloped countries. The prognosis is usually poor due to late diagnosis and aggressive characteristics. Studies have shown that questionnaires from the European Organization for Research and Treatment of Cancer objectively reflect the quality of these patients' lives, fundamental to ensure replicable results and comparison between different populations.

Aim: To describe the impact of antineoplastic treatment on the quality of life in patients with esophageal cancer through the EORTC basic and specific questionnaires.

Method: Systematic review of the PUBMED, CINAHL, SCOPUS, COCHRANE, EMBASE and PSYCINFO databases from 2003 to 2016. A librarian established the search strategy on the bases cited. Two researchers independently selected studies according to the inclusion criteria. Disagreements over studies to be included were resolved by discussion and consensus. Of the 203 records, eight complete texts were selected for analysis.

Results: In the EORTC QLQ-OES18 symptom scale, the most frequently mentioned complains were pain, problems with feeding, reflux, dry mouth and problems with taste. On the functional scale, dysphagia was reported in most studies.

Conclusion: HRQoL is temporarily affected in patients undergoing chemotherapy, with or without radiotherapy. Most domains improve or return to basal levels despite treatment toxicity. Those who survive a year or more after potentially curative treatment for esophageal cancer can lead a satisfactory life even with some of the functions affected in HRQoL.
\end{abstract}

Keywords: Quality of life; Questionnaires and surveys; Esophageal neoplasms; Chemotherapy; Radiotherapy; Neoadjuvant therapy.

\section{Introduction}

Esophageal cancer is in eighth position among the most common types worldwide, according to the International Agency for Research on Cancer. In 2012, 456,000 cases of esophageal neoplasia were identified, representing $3.2 \%$ of all new cases of cancer. Regarding mortality, of the estimated 400,000 cancer deaths in the world, $4.9 \%$ were due to esophageal cancer, which reached the sixth position. These numbers include the most common histological types, adenocarcinoma and squamous cell carcinoma ( $90 \%$ of cases). Approximately $80 \%$ of the world's cases occur in underdeveloped countries, with the incidence in men more than double that observed in women, that is, for each woman diagnosed with the disease, 2.4 men present the disease. In Brazil, the National Cancer Institute estimates that 7,950 new cases in the male population and 2,860 in the female population will occur in 2016/2017 [1,2].

The chances for the appearance of tumors in the esophagus increase with age, appearing more frequently after the 50 years. In addition to seeming to be associated with low socioeconomic status, the main etiological factors involve lifestyle such as abusive use of alcoholic beverages or hot drinks such as chimarrão, smoking, consumption of canned or salted foods, diet low in riboflavin, zinc and vitamins E, A and C, poor oral hygiene, occupational aspects such as prolonged exposure to silica dust, metals and polycyclic hydrocarbons; Infectious processes (Helicobacter pylori, Candida albicans and Papilloma virus); and diseases such as Zenker's diverticulum, Barrett's esophagus, hiatus hernia, gastroesophageal reflux, megaesophagus or Plummer-Vinson syndrome $[3,4,5]$.

The most common symptom is dysphagia, often referred to at the same level of tumor localization and when there is 50\% or more of esophageal lumen involvement. Generally, patients adjust to the difficulty of swallowing, gradually changing the intake of solid foods to liquids. It is common for rapid weight loss, odynophagia, regurgitation, dry mouth and palate alteration [5, 6]. About $80 \%$ of patients have locally advanced disease or metastasis at diagnosis, which limits curative treatment. In these cases, the treatment is multimodal, 
involving neoadjuvance with chemotherapy and / or radiotherapy exclusively or in combination. If there is a good therapeutic response, the surgical rescue can be proposed [7, 8].

The prognosis is generally poor due to late diagnosis and aggressive tumor characteristics [5]. However, advances in new diagnostic and treatment techniques have allowed for an increase in overall survival. Although life expectancy increased, quality of life (QoL) did not follow this improvement [9]. Health-related quality of life (HRQoL) is considered, along with disease-free survival, as one of the most important parameters for assessing the impact of antineoplastic treatment [10].

There are several instruments to evaluate QoL in cancer patients in the international literature, and the QLQ-C30 from the European Organization for Research and Treatment of Cancer (EORTC) is well recommended [11]. The instrument was designed to be applied in association with specific modules for each type of cancer, which in the case of esophageal tumors is EORTC QLQ-OES18. In a 2003 publication, Blazeby and cols. [12] found that EORTC QLQ-OES18 has good psychometric and clinical validity and recommended its use to assess QoL in patients with esophageal cancer. These same authors concluded that because of the good sensitivity and specificity of the questionnaires, it was possible to detect small benefits associated with various forms of treatment [12]. In addition to this publication, other studies have also shown that the combined use of QLQ-C30 and QLQ-OES18 objectively reflects QoL in patients with esophageal cancer, which has been shown to be fundamental to ensure replicable results and to allow comparison between different populations [13-18].

Thus, knowing the impact of antineoplastic treatment on the QoL of patients with esophageal cancer through the basic (QLQ-C30) and specific questionnaires (QLQ-OES18) could help health professionals to make their therapeutic decisions. Given the relevance of the topic, the interest in developing the study with the following research question emerged: which domains were negatively affected in the QoL of patients with esophageal cancer submitted to chemotherapy associated or not with radiotherapy. Thereby, our objective was to systematically review the literature on quality of life assessment using the instruments of the European Organization for Research and Treatment of Cancer in patients with esophageal cancer treated with radiotherapy associated or not with neoadjuvant or exclusive radiotherapy.

\subsection{Type of study}

\section{Method}

It is a systematic review, elaborated according to the following steps: formulation of the question, location of the records in the databases, critical evaluation of the studies, data collection, analysis and presentation of the data and interpretation of the data [19].

\subsection{Quality of life questionnaires}

The QLQ-C30 instrument was developed in 1986 by the EORTC with the aim of measuring QoL in a standardized way in oncology, facilitating its use in international studies. The questionnaire is multidimensional and self-administered, containing 30 questions that assess the patient in relation to symptoms, side effects of treatment, psychological suffering, physical functioning, social interaction, sexuality, body image, global health and general QoL, regardless of cancer type. It was planned to be applied in combination with specific modules for each type of cancer, which in the case of esophageal tumors is QLQ-OES18 [20, 21].

QLQ-OES18 was created in 1996 by the Academic Department of Surgery at the University of Bristol Royal Infirmary. The instrument covers specific esophageal cancer symptoms during the last week, such as dysphagia, eating, reflux, pain, difficulty swallowing saliva, choking on swallowing, dry mouth, taste problems, problems with coughing and speaking difficulty [22].

\subsection{Search Strategies}

The identification of the articles was carried out by searching the databases PUBMED, CINAHL, SCOPUS, COCHRANE, EMBASE and PSYCINFO, with a temporal cut from 2003 to 2016, published in Portuguese, English and Spanish. The search terms were "quality of life", "questionnaires", "eortc", "qlqc30", "qlqoes18", "cancer", "tumor", "esophageal neoplasms", "oncology", "chemotherapy", "drug Therapy "," radiotherapy" and "chemoradiotherapy". The intercession between the terms was made through the Boolean operators "AND", "OR" and "NOT". The search strategy was developed with the help of a clinical librarian (Figure 1). 


\begin{tabular}{|c|c|c|}
\hline & Estratégia de Busca & $\begin{array}{l}\text { Registros } \\
\text { encontrados }\end{array}$ \\
\hline $\begin{array}{l}\frac{O}{\frac{0}{c}} \\
\frac{r}{0} \\
\frac{0}{0} \\
0\end{array}$ & $\begin{array}{l}\text { quality of life AND ( questionnar* OR eortc OR QLQ-OES18 OR OES-18 ) AND ( chemo* OR drug therapy ) AND } \\
\text { Esophageal Neoplasms OR ( Esophag* OR oesophag* ) AND ( cancer OR tumor* }{ }^{*} \text { onco* OR neoplas* ) }\end{array}$ & 1 \\
\hline$\frac{\frac{\Gamma}{\frac{\pi}{\pi}}}{\frac{C}{0}}$ & $\begin{array}{l}\text { "quality of life" AND (questionnar\$ OR eortc OR QLQ-OES18 OR OES-18) AND (chemo* OR drug therapy) AND } \\
\text { "Esophageal Neoplasms" OR (Esophag\$ OR oesophag\$) AND (cancer OR tumor\$ OR onco\$ OR neoplas\$) }\end{array}$ & 5 \\
\hline 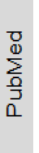 & $\begin{array}{l}\text { ('quality of life'/exp OR 'quality of life':ab,ti) AND ('questionnaires'/exp OR questionnair*ab,ti OR eortc:ab,ti OR 'qla- } \\
\text { oes18':ab,ti OR 'oes-18':ab,ti) AND ('drug therapy'/lexp OR chemotherap*:ab,ti OR chemoradiotherapy':exp OR } \\
\text { chemoradiat*:ab,ti) AND (esophag*:ab,ti OR oesophag":ab,ti) AND (cancer:ab,ti OR tumor*ab,ti OR onco*:ab,ti OR } \\
\text { neoplas*:ab,ti OR 'esophageal neoplasms'/exp) AND ([english/lim OR [portuguese]/lim OR [spanish]/lim) AND } \\
\text { [humans]/lim AND [abstracts]/lim AND ('article'/it OR 'article in press'/it OR 'conference paper'/it OR 'review'/it) }\end{array}$ & 70 \\
\hline 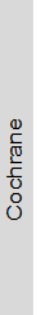 & 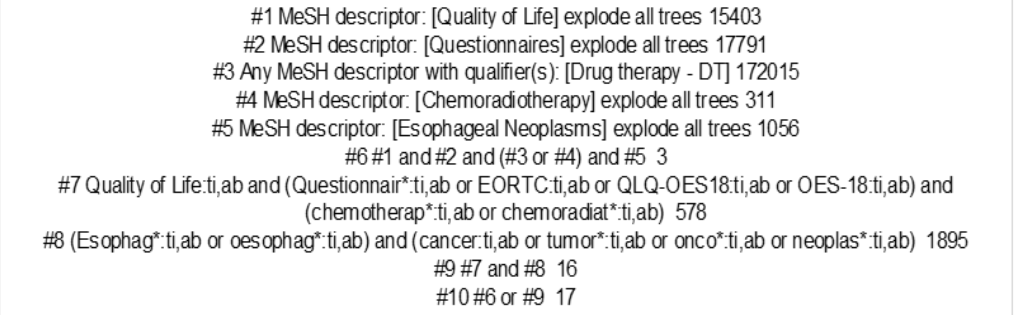 & 17 \\
\hline 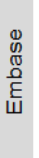 & $\begin{array}{l}\text { ('quality of life'/exp OR 'quality of life':ab,ti) AND ('questionnaires'/exp OR questionnair*:ab,ti OR eortc:ab,ti OR 'qlq- } \\
\text { oes18':ab,ti OR 'oes-18':ab,ti) AND ('drug therapy'/exp OR chemotherap*:ab,ti OR 'chemoradiotherapy':exp OR } \\
\text { chemoradiat*:ab,ti) AND (esophag*:ab,ti OR oesophag*:ab,ti) AND (cancer:ab,ti OR tumor*:ab,ti OR onco*:ab,ti OR } \\
\text { neoplas*:ab,ti OR 'esophageal neoplasms'/exp) AND ([english]/lim OR [portuguese]/lim OR [spanish]/lim) AND } \\
\text { [humans]/lim AND [abstracts]/lim AND ('article'/lit OR 'article in press'/it OR 'conference paper'/it OR 'review'/it) }\end{array}$ & 81 \\
\hline $\begin{array}{l}n \\
\overline{0} \\
0 \\
0 \\
\infty\end{array}$ & $\begin{array}{l}\text { quality of life AND (questionnar* OR eortc OR QLQ-OES18 OR OES-18) AND (chemo* OR drug therapy) AND Esophageal } \\
\text { Neoplasms OR (Esophag* OR oesophag*) AND (cancer OR tumor* OR onco* OR neoplas*) }\end{array}$ & 29 \\
\hline
\end{tabular}

Figure 1 - Search strategies

\subsection{Selection method:}

Based on the results of the initial searches, two researchers independently selected the studies that met the inclusion criteria. Differences in the choice of studies that should be included in the review were resolved through discussion and consensus. The data were extracted from original articles and organized into tables, including: main author, place of publication, periodical, year of publication, type of study, study sample, moments of application of scales, functions and domains affected.

\subsection{Inclusion and exclusion criteria:}

The following inclusion criteria were considered:

- Articles that addressed the evaluation of QoL in patients with esophageal cancer undergoing anticancer treatment (chemotherapy and / or radiotherapy), in a neoadjuvant or exclusive way, using the associated EORTC QLQ-C30 and QLQ-OES18 instruments;

- Articles published in Portuguese, English and Spanish;

- Articles available in full electronically;

- Articles published after 2003, year of publication of the EORTC QLQ-OES18 questionnaire.

The exclusion criteria established were:

- Articles that used instruments other than EORTC for the evaluation of QoL in patients with esophageal cancer;

- Duplicate articles;

- Abstracts published on congress proceedings;

- Articles that used EORTC QLQ-OES18 only in cases of surgical treatment, palliative care or placement of esophageal stents;

- Articles that used EORTC QLQ-OES18 for benign or cancer precursor diseases. 


\subsection{Selection of articles}

The selection of articles was initially based on the exploratory reading of the title and the summary of each reference, seeking identification with the theme. Initially, 203 records (publications) were identified. They were selected according to the inclusion and exclusion criteria established in the review method. The diagram of the search and selection of the studies for the review is described in the diagram of figure 2 .

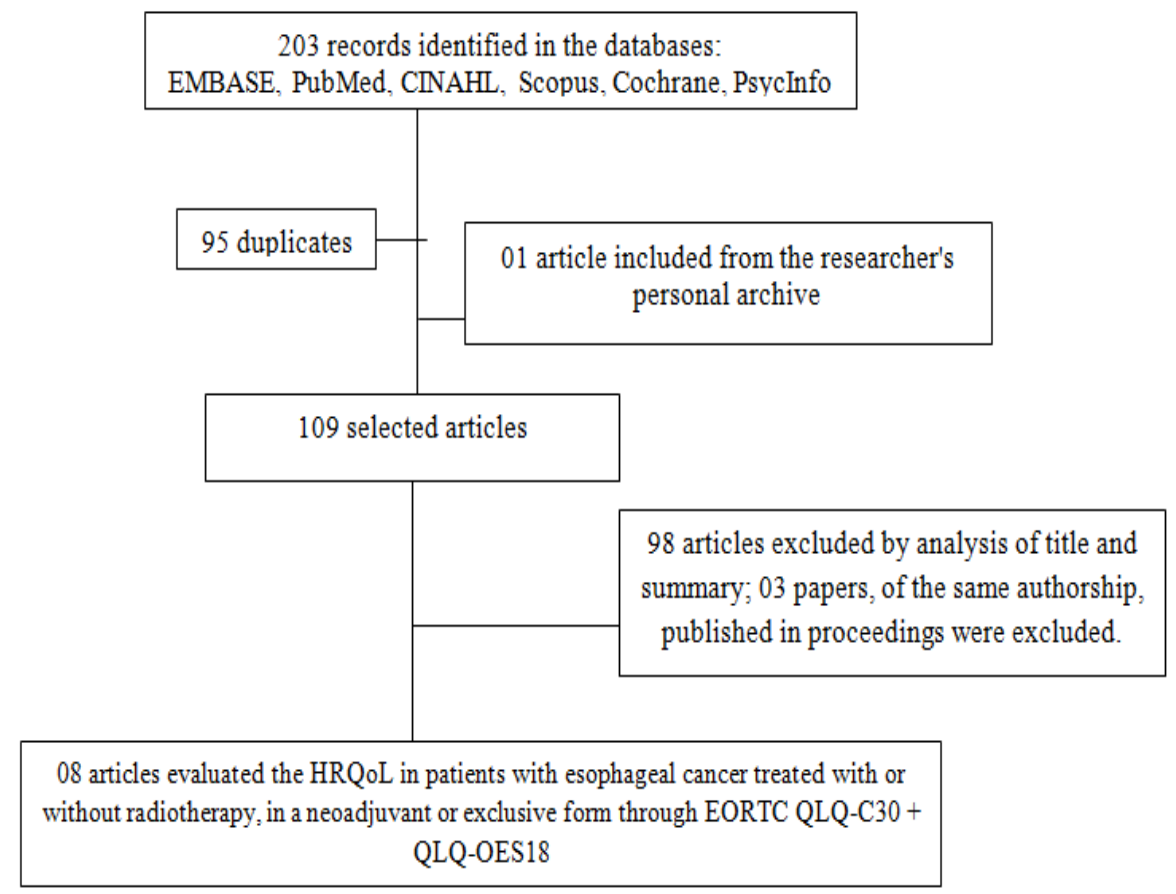

Figure 2. Diagram of the search and selection of the studies for the systematic review

\section{Results}

As described in figure 2, we selected 07 articles from the electronic search and one article from the researcher's personal archive, based on the inclusion and exclusion criteria, making a total of 08 articles for analysis. The main features of the selected articles are summarized and arranged in chronological order in Table 1 .

Table 1. Summary of main characteristics of selected studies

\begin{tabular}{|l|l|l|l|l|}
\hline $\begin{array}{l}\text { Main } \\
\text { Author }\end{array}$ & $\begin{array}{l}\text { Country of } \\
\text { study }\end{array}$ & Journal & $\begin{array}{l}\text { Year of the } \\
\text { publication }\end{array}$ & $\begin{array}{l}\text { Type of } \\
\text { study }\end{array}$ \\
\hline J.M. Blazeby et al. & United Kingdom & Cancer & 2005 & Comparative prospective \\
\hline E. van Meerten et al. & Netherlands & $\begin{array}{l}\text { International Journal of Radiation } \\
\text { Oncology }\end{array}$ & 2008 & Longitudinal \\
\hline H. N. K. Ariga, et al. & Japan & $\begin{array}{l}\text { International Journal of Radiation } \\
\text { Oncology }\end{array}$ & 2009 & Transversal \\
\hline E. F. W. C. Staal et al. & Netherlands & $\begin{array}{l}\text { Journal of Thoracic and } \\
\text { Cardiovascular Surgery }\end{array}$ & Comparative Transversal \\
\hline M. Hurmuzlu et al. & Norway & Diseases of the Esophagus & 2011 & Longitudinal comparative \\
\hline K. Kataria et al. & India & Saudi Journal of Gastroenterology & 2012 & Comparative prospective \\
\hline M. Scarpa et al. & Italy & $\begin{array}{l}\text { Journal of Gastroenterology } \\
\text { Surgery }\end{array}$ & 2013 & Prospective \\
\hline J. Rees et al. & United Kingdom & British Journal of Cancer & 2015 & Multicenter clinical trial \\
\hline
\end{tabular}

As can be seen in Table 1, most studies were conducted in developed countries. Only one was developed in India. The publications were distributed between the years 2005 and 2015. The type of treatment, the sample size and the moments of application of the questionnaires are described in Table 2. Six studies evaluated the quality of life before the start of treatment and after the end of the therapeutic proposal. Two studies evaluated the quality of life of patients with esophageal cancer late, without evaluate HRQoL before or during treatment, ranging from one to three years after the end of treatment with curative intent. 
Table 2. Types of treatments and moments of application of questionnaires

\begin{tabular}{|c|c|c|c|}
\hline $\begin{array}{l}\text { Main } \\
\text { Author }\end{array}$ & $\begin{array}{l}\text { Type of treatment and distribution of the sample } \\
\text { by groups analyzed }\end{array}$ & $\begin{array}{l}\text { Total } \\
\text { sample }\end{array}$ & $\begin{array}{l}\begin{array}{l}\text { Moments of } \\
\text { questionnaires }\end{array} \\
\end{array}$ \\
\hline $\begin{array}{l}\text { J.M. Blazeby et al., } \\
2005 \text { [23] }\end{array}$ & $\begin{array}{l}\text { Group 1- CT + RT concomitant + Surgery: } \mathrm{n}=34 \\
\text { Group } 2 \text { - CT + Surgery: } \mathrm{n}=48 \\
\text { Group } 3 \text { - Surgery: } \mathrm{n}=21\end{array}$ & 103 & $\begin{array}{l}\text { Before and after } 7 \text { weeks of onset } \\
\text { CT and / or RT; Before and after } \\
\text { surgery. }\end{array}$ \\
\hline $\begin{array}{l}\text { E. van Meerten et al., } \\
2008[24]\end{array}$ & $\mathrm{CT}+\mathrm{RT}$ concomitant + Surgery: $\mathrm{n}=54$ & 54 & $\begin{array}{l}\text { Before start and } 01 \text { week after the } \\
\text { end of concomitant CT }+ \text { RT; 03, } \\
06,09 \text { and } 12 \text { months after surgery. }\end{array}$ \\
\hline $\begin{array}{l}\text { H. N. K. Ariga et al., } \\
2009 \text { [25] }\end{array}$ & $\begin{array}{l}\text { Group 1- CT + RT: } \mathrm{n}=56(37 \text { completed the } \\
\text { treatment }) \\
\text { Group } 2-\text { Surgery: } \mathrm{n}=48(25 \text { completed the } \\
\text { treatment })\end{array}$ & 104 & After 2 years of treatment. \\
\hline $\begin{array}{l}\text { E. F. W. C. Staal et al., } \\
2010[26]\end{array}$ & $\begin{array}{l}\text { Group 1- CT + RT: } \mathrm{n}=06 \\
\text { Group } 2-\mathrm{CT}+\text { Surgery: } \mathrm{n}=21 \\
\text { Group } 3 \text { - Surgery: } \mathrm{n}=09 \\
\text { These three groups were compared to a group of } \\
\text { patients with esophageal cancer at different stages } \\
\text { of the disease }(\mathrm{n}=1031) \text { and another group of the } \\
\text { non-cancer population }(\mathrm{n}=7,802) \text {. }\end{array}$ & 36 & After 1 year of treatment. \\
\hline $\begin{array}{l}\text { M. Hurmuzlu et al., } \\
2011 \text { [27] }\end{array}$ & $\begin{array}{l}\text { Group } 1 \text { - Surgery: } \mathrm{n}=20 \\
\text { Group } 2-\mathrm{CT}+\mathrm{RT} \text { concomitant and in high doses } \\
+ \text { Surgery: } \mathrm{n}=21 \\
\text { These two groups were compared to each other and } \\
\text { to another three groups }(01 \text { of patients treated and } \\
\text { free of disease: } \mathrm{n}=96 ; 01 \text { of laryngectomized } \\
\text { patients: } \mathrm{n}=104 ; \text { and } 01 \text { of the Norwegian } \\
\text { population without cancer: } \mathrm{n}=3,000\end{array}$ & 41 & Before treatment and 1 year after. \\
\hline $\begin{array}{l}\text { K. Kataria et al., } 2012 \\
\text { [28] }\end{array}$ & $\begin{array}{l}\text { Group 1- CT + Surgery + RT: } \mathrm{n}=15 \\
\text { Group } 2 \text { - Surgery + RT: } \mathrm{n}=15\end{array}$ & 30 & $\begin{array}{l}\text { Before CT, before surgery and } 16 \\
\text { weeks after the end of Rt. }\end{array}$ \\
\hline $\begin{array}{l}\text { M. Scarpa et al., } 2013 \\
\text { [29] }\end{array}$ & CT + Surgery: $n=126$ & 126 & $\begin{array}{l}\text { Before and after CT; At discharge } \\
\text { after surgery and } 01,03,06 \text { and } 12 \\
\text { months after surgery. }\end{array}$ \\
\hline J. Rees et al., 2015 [30] & $\begin{array}{l}\text { Grupo } 1-\mathrm{CT}+\mathrm{RT}: \mathrm{n}=129 \\
\text { Grupo } 2-\mathrm{CT}+\mathrm{RT}+\text { cetuximab: } \mathrm{n}=129 \\
\text { PS: Cetuximab is a monoclonal antibody that } \\
\text { competes with EGFR. This paper is part of the } \\
\text { results of the international multicenter clinical trial } \\
\text { SCOPE-1. }\end{array}$ & 258 & $\begin{array}{l}02 \text { weeks before treatment and after } \\
07,13,24,52 \text { and } 104 \text { weeks of } \\
\text { initiation of treatment. }\end{array}$ \\
\hline
\end{tabular}

Note: $\mathrm{CT}=$ Chemotherapy; RT = Radiation therapy; EGFR = Epidermal Growth Factor Receptor.

The results of the evaluation of HRQoL performed in the studies selected for analysis are summarized in Table 3. In each article, the aspects related to the impact of chemotherapy, whith or not accompanied by radiotherapy, on the HRQoL of the treated patients were searched.

Table 3. Summary of articles selected for review.

\begin{tabular}{|c|c|}
\hline $\begin{array}{l}\text { Main } \\
\text { Author }\end{array}$ & Summary of results \\
\hline $\begin{array}{l}\text { J.M. Blazeby et al., } 2005 \\
\text { [23] }\end{array}$ & 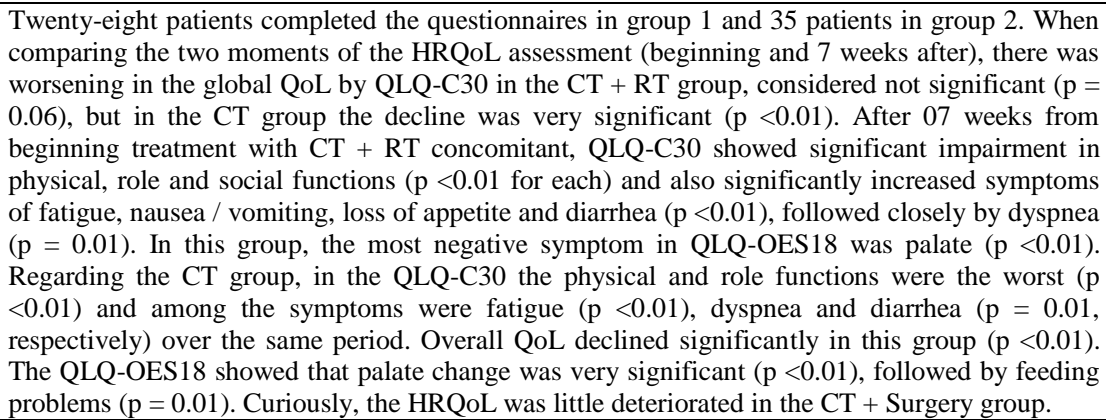 \\
\hline $\begin{array}{l}\text { E. van Meerten et al., } 2008 \\
\text { [24] }\end{array}$ & $\begin{array}{l}\text { Of the } 54 \text { patients selected, } 49 \text { answered the questionnaires. Significant decline in HRQoL was } \\
\text { identified globally. In QLQ-C30, the most impaired functions were physical and role after } \\
\text { concomitant CT + RT. The emotional function presented the same score from the beginning to } \\
\text { the end of the concomitant CT + RT. At this stage of treatment, the most affected functions were } \\
\text { cognitive and social. The five most affected symptoms in QLQ-C30, in descending order, were } \\
\text { fatigue, loss of appetite, pain, nausea / vomiting, and dyspnea. The maximum score was recorded } \\
\text { shortly after the end of treatment. In QLQ-OES18, concomitant CT + RT treatment caused } \\
\text { greater impact on symptoms such as problems with eating, dysphagia, palate alterations, pain and } \\
\text { cough. They concluded that complete treatment, including surgery, had a profound negative } \\
\text { impact on most aspects of HRQoL, but they were temporary because patients recovered within } 1\end{array}$ \\
\hline
\end{tabular}




\begin{tabular}{|c|c|}
\hline & $\begin{array}{l}\text { year after esophagectomy. They also infer that HRQoL assessment provides additional } \\
\text { information on the toxicity of CT }+\mathrm{RT} \text {. }\end{array}$ \\
\hline $\begin{array}{l}\text { H. N. K. Ariga et al., } 2009 \\
\text { [25] }\end{array}$ & $\begin{array}{l}\text { The HRQoL assessment was performed after the end of treatment, from } 28.2 \text { to } 61.1 \text { months, } \\
\text { averaging } 49.7 \text { months. For the study of HRQoL, only } 30 \text { patients answered the questionnaires in } \\
\text { the CT + RT group and } 20 \text { others in the surgery group. For QLQ-C30 after } 2 \text { years of treatment } \\
\text { completion, the surgery group had the worst overall QoL score, } 72.3 \text { points versus } 82.5 \text { in the CT } \\
+ \text { RT group. The social function was the most impaired }(\mathrm{p}=0.054) \text { and the symptoms were loss } \\
\text { of appetite }(\mathrm{p}=0.003) \text { and diarrhea }(\mathrm{p}=0.002) \text { along with pain }(\mathrm{p}=0.057) \text {. The QLQ-OES18 } \\
\text { showed problems with feeding as significantly poor }(\mathrm{p}=0.004) \text { in the same group (surgery). The } \\
\text { study obtained a small sample for the evaluation of HRQL, which impaired the analyzes, but a } \\
\text { better QoL was attributed to the group that did CT + RT. }\end{array}$ \\
\hline $\begin{array}{l}\text { E. F. W. C. Staal et al., } 2010 \\
\text { [26] }\end{array}$ & $\begin{array}{l}\text { The sample of } 36 \text { patients was submitted to different treatments and no comparison was made } \\
\text { between them. They were grouped and compared to a group of patients with esophageal cancer at } \\
\text { different stages of the disease }(\mathrm{n}=1031) \text { and another group of the non-cancer population }(\mathrm{n}= \\
7,802) \text {. In QLQ-C30, overall QoL was considered good }(77 \text { points, SD }=19) \text { in the study group, } \\
\text { better than the other two groups used for comparison }(\mathrm{p}<0.001) \text {. Also, there was better emotional } \\
\text { function, less pain and less constipation ( } \mathrm{p}<0.001) \text {. The exceptions were for cognitive function, } \\
\text { diarrhea and financial difficulties, although the differences did not reach statistical significance. } \\
\text { Through QLQ-OES18, it was found that } 50 \% \text { of the study group still had dysphagia after } 1 \text { year } \\
\text { post-treatment, but less pain and palate changes }(\mathrm{p}<0.001) \text {. One weakness of the study was the } \\
\text { grouping of patients who underwent different antineoplastic treatments to compare with the other } \\
\text { two groups, over which the authors did not have sufficient clinical information. The authors state } \\
\text { that the duration of survival for patients with esophageal cancer does not influence the quality of } \\
\text { life scores. }\end{array}$ \\
\hline $\begin{array}{l}\text { M. Hurmuzlu et al., } 2011 \\
\text { [27] }\end{array}$ & $\begin{array}{l}\text { The CT + RT group, when compared to QLQ-C } 30 \text { who underwent exclusive surgery, showed a } \\
\text { worse overall QoL }(\mathrm{p}=0.018) \text { one year after treatment. Among the functions, the worst were } \\
\text { physical }(\mathrm{p}=0.004) \text {, social }(\mathrm{p}=0.020) \text { and emotional }(\mathrm{p}=0.053) \text {. The most significant } \\
\text { symptoms were pain }(\mathrm{p}=0.004) \text { and fatigue }(\mathrm{p}=0.005) \text {. However, QLQ-OES18, according to } \\
\text { the authors, did not show significant differences between the CT + RT groups and the exclusive } \\
\text { surgery, but did not show these results. It was concluded that the two groups that had esophageal } \\
\text { cancer presented worse HRQoL after } 1 \text { year, when compared to the other groups (treated and free } \\
\text { of disease, laryngectomized, and Norwegian population without cancer), mainly with the } \\
\text { Norwegian population. }\end{array}$ \\
\hline $\begin{array}{l}\text { K. Kataria et al., } 2012 \\
\text { [28] }\end{array}$ & $\begin{array}{l}\text { When comparing the two groups through QLQ-C } 30 \text { at the beginning and at the end of treatment, } \\
\text { it was noted that there was a significant improvement in overall QoL in the two groups, more } \\
\text { evident in group I, CT }+ \text { Surgery }+\mathrm{RT}(\mathrm{p}=0.006) \text {, than in group II, of Surgery }+\mathrm{RT}(\mathrm{p}=0.019) \text {. } \\
\text { As for the symptoms, the two groups had an increase in the score of financial problems. Social } \\
\text { and role functions showed worsening in both groups. The worsening of social function was } \\
\text { significant ( } \mathrm{p}=0.035 \text { in group I and } \mathrm{p}=0.003 \text { in group II), while worsening in role performance } \\
\text { was not significant. Evaluation through QLQ-OES18 showed that the improvement of pain and } \\
\text { dyspnea was significant in group I }(\mathrm{p}=0.019 \text { and } \mathrm{p}=0.020) \text {. The authors concluded that global } \\
\text { QoL was better for group I and that symptoms such as nausea / vomiting and financial problems } \\
\text { continue to worsen in group II. }\end{array}$ \\
\hline $\begin{array}{l}\text { M. Scarpa et al., } 2013 \\
\text { [29] }\end{array}$ & $\begin{array}{l}\text { Of the } 126 \text { patients included in the study, } 97 \text { answered the questionnaires and did neoadjuvant } \\
\text { treatment, CT }(\mathrm{n}=42) \text { or CT }+\mathrm{RT}(\mathrm{n}=55) \text {, and surgery. Evaluation by QLQ-C30 revealed an } \\
\text { improvement in overall QoL after neoadjuvant treatment and worsened after surgery }(\mathrm{p}=0.04) \text {, } \\
\text { which was recovered in part after } 6 \text { months postoperatively. The most affected functions after } \\
\text { neoadjuvance were physical and role performance ( }<<0.01 \text { respectively), as well as the fatigue, } \\
\text { pain and diarrhea symptoms with } \mathrm{p}<0.01 \text { for each. Fatigue and pain improved with } 06 \\
\text { postoperative months, but diarrhea persisted. Dyspnea, insomnia, and loss of appetite intensified } \\
\text { significantly ( } \mathrm{p}<0.01) \text { after surgery. As for QLQ-OES18, dysphagia improved after neoadjuvant } \\
\text { (non-significant) treatment and decreased even more after surgery (p }<0.01) \text {. They concluded that } \\
\text { the patients who presented less dysphagia and pain after the neoadjuvant treatment were the ones } \\
\text { that recovered better during the postoperative period. }\end{array}$ \\
\hline $\begin{array}{l}\text { J. Rees et al., } 2015 \\
{[30]}\end{array}$ & $\begin{array}{l}\text { The questionnaires were answered by } 122 \text { patients in group I of CT + RT and } 124 \text { in group II of } \\
\text { CT + RT + Cetuximab in the SCOPE-1 trial. At the start of the study, QLQ-C30 global QoL } \\
\text { scores were elevated in more than } 75 \% \text { of patients, ranging from } 63.3 \text { to } 72.3 \text { points for the CT + } \\
\text { RT group and between } 64.9 \text { and } 71.8 \text { points for the group that did CT + RT + Cetuximab. } \\
\text { Through QLQ-OES18, at the beginning, the worst symptoms were problems with feeding and } \\
\text { dysphagia. Serious problems with fatigue, insomnia, and loss of appetite occurred in both groups } \\
\text { after initiation of treatment. Around } 03 \text { months and } 1 \text { week, according to QLQ-OES18, symptoms } \\
\text { increased with treatment and more problems with fatigue, dyspnea, loss of appetite and problems } \\
\text { with taste in the } 2 \text { groups were reported. Comparing the groups by the QLQ-C30 in this period, } \\
\text { the CT + RT group presented higher scores on loss of appetite and fatigue and that on the CT + } \\
\text { RT + Cetuximab group, with worse performance, the highest scores were for the same symptoms, } \\
\text { Dyspnea and insomnia. In the global QoL, the physical role and social function deteriorated } \\
\text { significantly. For QLQ-OES18, the CT + RT + Cetuximab group also had a greater impact on } \\
\text { problems with feeding, taste alteration, dysphagia, dry mouth and cough. In the CT + RT group } \\
\text { the major negative changes were for dysphagia, problems with taste and feeding. The recovery } \\
\text { occurred after } 6 \text { months, except for severe fatigue and insomnia in more than } 15 \% \text { of the patients } \\
\text { and remained in the follow-up without significant differences between the groups, according to } \\
\text { the authors. }\end{array}$ \\
\hline
\end{tabular}

Note: $\mathrm{CT}=$ Chemotherapy; $\mathrm{RT}=$ Radiotherapy, $\mathrm{QoL}=$ Quality of life; HRQoL $=$ Health-related quality of life. 


\section{Final Considerations}

HRQoL has been found to vary widely from country to country. The reasons may be linked to social, economic, cultural and emotional determinants of each region, which interferes in the education of the patient and the professionals regarding therapeutic practices and decision making.

In summary, in relation to the functional scales of the QLQ-C30 instrument, the physical function was pointed out as the most affected. In the scale of symptoms, the same was true for fatigue. In the specific esophageal cancer module, the QLQ-OES18, the most commonly reported symptom in the patients was pain, and on the functional scale was dysphagia. However, it is perceived that HRQoL is temporarily affected in patients submitted to chemotherapy with and without radiotherapy and most domains improve or return to basal levels despite treatment toxicity.

Patients who survive one year or more after potentially curative treatment for esophageal cancer can lead a satisfactory life, even with some of the functions affected in the HRQoL. The evaluation of HRQoL should be considered as an important factor in the decision-making of the professional, because, besides identifying which functions are affected in these individuals during the treatment, it can provide subsidies to clarify to the patient the harmful effects that can be experienced long term.

After reading the abstracts for the selection of the articles of this systematic review, we realized that, despite the good psychometric and clinical validity of the EORTC QLQ-OES18, many authors did not use it to evaluate the HRQoL of patients with esophageal cancer, especially when Chemoradiotherapy is a neoadjuvant or exclusive treatment. This discourages the publication of replicable studies in other populations so that comparisons of results are made. The specific questionnaire for esophageal cancer has been more frequently used in comparative studies of HRQoL in patients undergoing different types of esophagectomy.

It is also worth noting that, in Brazil, no studies on cross-cultural adaptation and reproducibility of the QLQ-OES18 instrument were found, nor were articles reported on the evaluation of HRQoL in patients with esophageal cancer through specific questionnaires for this disease.

\section{Acknowledgements}

We are grateful for the valuable help of Librarian Camila Belo Tavares Ferreira (Cancer Hospital I - Br $\mathrm{NCI}$ ), who elaborated the search strategy for this systematic review.

\section{References}

[1] International Agency for Research on Cancer. GLOBOCAN 2012: Estimated Incidence, Mortality and Prevalence Worldwide in 2012. Oesophageal Cancer. 〈http://globocan.iarc.fr/Pages/fact_sheets_cancer.aspx>.

[2] Brasil. Instituto Nacional de Câncer. Estimativa 2016: Incidência de Câncer no Brasil. Coordenação de Prevenção e Vigilância, (Rio de Janeiro, RJ: INCA, 2016).

[3] M.A.V. Rêgo, A. A. Fonseca. Trend of Esophageal Cancer Mortality in Salvador City and in the State of Bahia, Brazil, 1980 to 2012, Revista Brasileira de Cancerologia, 60(1), 2014, 25-33.

[4] A. A. Ribeiro, A. C. Nardocci. Socioeconomic inequalities in cancer incidence and mortality: review of ecological studies, 19982008, Saúde Social, 22(3), 2013, 878-91.

[5] N. M. Monteiro et al. Esophageal cancer: Profile of manifestations, histology, location and metastic behavior in patients undergoing cancer treatment at a Cancer Center in Minas Gerais, Revista Brasileira de Cancerologia, 55(1), 2009, 27-32.

[6] W.C. Chie et al. Quality of life of patients with oesophageal cancer in Taiwan: Validation and application of the Taiwan Chinese (Mandarin) version of the EORTC QLQ-OES18: A brief communication, Quality of Life Research, 19(8), 2010, 1127- 1131.

[7] P.M.G. Hoff, Tratado de Oncologia (São Paulo, SP: Editora Atheneu. 2013).

[8] R. C. Queiroga, A. P. Pernambuco. Esophageal cancer: Epidemiology, diagnosis, and treatment, Revista Brasileira de Cancerologia, 52(2), 2006, 173-178.

[9] A. P. Zandonai et al. Quality of life in cancer patients: integrative review of Latin American literature, Revista Eletrônica de Enfermagem, 12(3), 2010, 554-561.

[10] D. Dorcaratto et al. Quality of life of patients with cancer of the oesophagus and stomach, Cirugía Española, 89(10), 2011, 635644.

[11] P.M. Fayers et al., The EORTC QLQ-C30 Scoring Manual. 3rd ed. Brussels: European Organisation for Research and Treatment of Cancer (Brussels, BE: EORTC, 2001).

[12] J. M. Blazeby et al. Clinical and psychometric validation of an EORTC questionnaire module, the EORTC QLQ-OES18, to assess quality of life in patients with oesophageal cancer, Europe Journal Cancer. 39(10), 2003, 1384-1394.

[13] M. Forootan et al. Adaptation of a quality of life questionnaire for Iranian patients with esophageal cancer. Indian J Palliat Care, 20(2), 2014, 123-127.

[14] G. E. Darling. Quality of Life in Patients with Esophageal Cancer, Thoracic Surgery Clinics, 23(4), 2013, 569-575.

[15] A. C. I. Ibáñez, M. F. A. Sierra, R. Sánchez. Cross-cultural adaptation of the EORTC QLQ-OES18 questionnaire to measure quality of life in patients with esophageal cancer in Colombia, Revista Colombiana Cancerologia, 17(2), 2013, 69-76.

[16] J. Zeng, J. S. Liu. Quality of life after three kinds of esophagectomy for cancer, World Journal of Gastroenterology, 18(36), 2012, 5106-5113.

[17] T. Djärv, P. Lagergren. Six-month postoperative quality of life predicts long-term survival after oesophageal cancer surgery, European Journal of Cancer, 47(4), 2011, 530-35.

[18] O.M. Fagevik et al. Physical function and quality of life after thoracoabdominal oesophageal resection. Results of a follow-up study, Dig Surg, 22(1-2), 2005, 63-68.

[19] R.F,Sampaio and M.C, Mancini, Systematic review studies: A guide for careful synthesis of scientific evidence, Revista Brasileira de Fisioterapia, 11(1), 2007, 83-9. 
[20] A.Bowling, What things are important in people's lives? A survey of the public's judgements to inform scales of health-related quality of life, Social Science e Medicine, 41 (10), 2015, 1447-1462.

[21] M. Klee, M. Groenvold and D. Machin, Quality of life of Danish women: Population-based norms for the EORTC QLQ-C30, Quality of Life Research 6(1), 1997, 27-34.

[22] J.M. Blazeby, D. Alderson, K. Winstone et al., Development of an EORTC questionnaire module to be used in quality of life assessment for patients with oesophageal cancer, The EORTC Quality of Life Study Group, Eur J Cancer, 32A(11), $1996,1912-7$.

[23] J.M. Blazeby, E. Sanford, S.J. Falk, et al., Health-related quality of life during neoadjuvant treatment and surgery for localized esophageal carcinoma, Cancer, 103(9), 2005, 1791-1799.

[24] E. V. Meerten, A. V. Gaast, C.W.N. Looman, et al., Quality of life during neoadjuvant treatment and after surgery for resectable esophageal carcinoma, International Journal of Radiation Oncology Biology Physics, 71(1), 2008, 160-166.

[25] H.Ariga, K. Nemoto, S. Miyazaki, et al, Prospective comparison of surgery alone and chemoradiotherapy with selective surgery in resectable squamous cell carcinoma of the esophagus, International Journal of Radiation Oncology Biology Physics, 75(2), 2009, 348-356.

[26] E. F. W. C. Staal, J.W.V. Sandick, et al., Health-related quality of life in long-term esophageal cancer survivors after potentially curative treatment, Journal of Thoracic and Cardiovascular Surgery, 140(4), 2010, 777-783.

[27] M. Hurmuzlu, H.J. Aarstad, A. K. H. Aarstad, et al., Health-related quality of life in long-term survivors after high-dose chemoradiotherapy followed by surgery in esophageal cancer, Diseases of the esophagus, 24(1), 2011, 39-47.

[28] K. Kataria, G. R. Verma, A. Malhotra and R. Yadav, Comparison of quality of life in patients undergoing transhiatal esophagectomy with or without chemotherapy, Saudi Journal of Gastroenterology, 18(3), 2012, 195-200.

[29] M. Scarpa, L.M. Saadeh, A. Fasolo, et al, Health-Related Quality of Life in Patients with Oesophageal Cancer: Analysis at Different Steps of the Treatment Pathway, Journal of Gastrointestinal Surgery, 17(3), 2013, 421-433.

[30] J. Rees, C. N. Hurt, S. Gollins, et al., Patient-reported outcomes during and after definitive chemoradiotherapy for oesophageal cancer, British Journal of Cancer, 113(4), 2015, 603-610. 